\title{
ESKALASI KOMITMEN TERHADAP PROYEK-PROYEK YANG TIDAK MENGUNTUNGKAN : PENGARUH LATAR BELAKANG PENDIDIKAN DAN PENGUNGKAPAN INFORMASI SEBAGAI PEMODELAN VARIABEL
}

\author{
Oleh : \\ Hari Sulistiyo \\ Fakultas Ekonomi dan Bisnis, Universitas Singaperbangsa Karawang \\ hari.sulistiyo@fe.unsika.ac.id \\ DOI Artikel : https://doi.org/10.34308/eqien.v6i2.97
}

\begin{tabular}{l}
\hline Article Info \\
\hline Article History: \\
Received 03 Agustus 2019 \\
Accepted 17 Agustus 2019 \\
Available Online 05 September \\
2019
\end{tabular}

Keyword :

Framing effects, commitment escalation, experimental design

\section{PENDAHULUAN}

Latar belakang pendidikan seseorang adalah hal yang mudah dilihat dan digunakan sebagai tolak ukur seseorang dikatakan professional atau tidak. Perbedaan latar belakang pendidikan akan membuat seseorang terspesialisasi dalam pekerjaannya. Latar belakang pendidikan akan menentukan pola pikir dan wawasannya dan akhirnya membentuk kepribadian seseorang. Hal ini menjadi menarik, apabila mahasiswa yang menempuh pendidikan pada Fakultas yang sama, yakni Faklutas Ekonomi dan Bisnis dengan dua Program Studi yang berbeda, yakni
Manajemen dan Akuntansi dalam menyikapi bagaimana pengambilan keputusan tentang keberlanjutan proyek yang tidak menguntungkan, apakah akan diteruskan atau dihentikan.

Pendidikan akuntansi harus menghasilkan akuntan yang profesional sejalan dengan perkembangan kebutuhan akan jasa akuntansi pada abad mendatang. Pendidikan akuntansi di indonesia bertujuan menghasilkan lulusan yang beretika dan bermoral tinggi. Berbagai upaya untuk memperkenalkan nilai-nilai profesi sebagai seorang akuntan yang profesional kepada mahasiswa. Menurut Suwardjono 
(2005) pengetahuan terhadap ilmu akuntansi dapat dipandang dari dua sisi pengertian yaitu sebagai pengetahuan profesi (keahlian) yang dipraktekkan di dunia nyata dan sekaligus sebagai suatu disiplin pengetahuan yang diajarkan di perguruan tinggi. Sedangkan Manajemen adalah ilmu, yang berarti kemampuan untuk menganalisis suatu permasalahan secara keilmuan sehingga dapat dianalisa, di telaah dan akhirnya dapat dilakukan transfer knowledge kepada pihak lain. Andrew F. Sikukula (Dalam Hasibun, 2009:6), mengemukakan bahwa manaen pada umumnya dikaitkan dengan aktifitas-aktifitas perencanaan, pengorganisasian, pengendalian, penempatan, pengarahan, pemotivasian, komunikasi dan pengambilan kjeputusan yang dilakukan oleh setiap organisasi dengan tujuan untuk mengkoordinasikan sebagai sumberdaya yang dimiliki oleh perusahaan sehingga akan di hasilkan suatu produk atau jasa secara efesien. Diharapkan dengan latar belakang pengetahuan yang berbeda ini, apabila kelak menjadi seorang manajer, mampu menggunakan pengetahuannya untuk proses pengambilan keputusan yang rasional dalam dunia kerja.

Namun, dalam banyak kasus dan ditunjukkan dengan penelitian-penelitian yang pernah dilakukan bukan hanya latar belakang pendidikan yang mampu mempengaruhi seeorang dalam pengambilan keputusan. Khususnya dalam hal pembuatan keputusan dalam meneruskan atau menghentikan proyek yang tidak menguntungkan. Seorang manajer yang bertanggung jawab untuk membuat keputusan awal untuk berinvestasi dalam proyek biasanya akan memiliki kecenderungan untuk "over-komit" sumber daya tambahan untuk proyek (Staw, 1976, 1981; Staw dan Fox, 1977; Staw dan Ross, 1978, 1980). Hal seperti ini sering disebut dengan Eskalasi komitmen, dimana terdapat tendensi perilaku para pengambil keputusan untuk bertahan atau mengeskalasi komitmennya pada serangkaian tindakan yang gagal (Brockner, 1992). Bazerman (1994, dalam Suartana, 2010:110) menemukan bahwa kecenderungan untuk eskalasi komitmen secara signifikan dipengaruhi oleh tiga hal berikut:

1. Derajat kekecewaan yang dirasakan oleh pembuat keputusan ketika umpan balik negatif dari keputusan awal diperoleh.

2. Persepsi tentang pentingnya keputusan tersebut.

3. Persepsi hubungan antara kedua keputusan.
Eskalasi komitmen juga dapat dijelaskan dengan menggunakan self-justification theory dan agency theory Brockner (1992).. Self justification theory menjelaskan bahwa manajer yang terlibat dari awal pada suatu proyek akan cenderung melanjutkan proyek tersebut walaupun keadaan ekonomi menunjukkan bahwa proyek tersebut mengalami kerugian dibandingkan dengan manajer yang tidak terlibat dari awal. Ada pula teori agensi yang berbeda dalam menerangkan eskalasi, yaitu sebagai tindakan yang rasional bagi agen sebagai pengambil keputusan (Kanodia et al., 1989 dan Harrel dan Harrison, 1994). Agency theory menjelaskan bahwa individu dimotivasi untuk mengambil keputusan yang memaksimalkan kepentingan ekonomi pribadi mereka (Effriyanti, 2005). Pada agency theory juga disebutkan dua kondisi yang mendorong manajer untuk melakukan eskalasi komitmen:

1. Incentive to Shirk.

merupakan kondisi yang terjadi ketika kepentingan manajer berbeda dengan kepentingan perusahaan, dan hal ini mengakibatkan manajer mengabaikan kepentingan perusahaan dan lebih mementingkan kepentingan pribadinya.

2. Asymmetry Information.

Asymmetry information merupakan kondisi yang terjadi pada saat terdapat informasi yang tidak simetris, artinya dalam hal ini terdapat informasi privat yang dimiliki oleh manajer. Dengan kata lain asimetri informasi muncul ketika manajer lebih mengetahui informasi internal dan prospek perusahaan di masa yang akan datang dibandingkan pemegang saham dan stakeholder lainnya (Rahmawati, Yacob, dan Nurul, 2006).

Rahmawati dkk. (2006) menyebutkan bahwa terdapat dua tipe asimetri informasi, antara lain:

a. Adverse selection

adalah jenis asimetri informasi dimana satu pihak atau lebih yang melangsungkan suatu transaksi usaha memiliki informasi lebih atas pihak-pihak lain. Adverse selection terjadi karena manajer dan para pihak dalam perusahaan lebih mengetahui kondisi kini dan prospek ke depan suatu perusahaan daripada investor. 


\section{b. Moral Hazard}

adalah jenis asimetri informasi dimana satu pihak atau lebih yang melangsungkan suatu transaksi usaha dapat mengamati tindakantindakan mereka dalam penyelesaian transaksi-transaksi mereka sedangkan pihak-pihak lainnya tidak. Moral hazard dapat terjadi karena adanya pemisahan pemilikan dengan pengendaliaan yang merupakan karakteristik kebanyakan perusahaan besar. Dengan kata lain moral hazard adalah kondisi dimana tidak semua tindakan yang dilakukan manajer diketahui oleh investor, sehingga manajer dapat melakukan tindakan di luar pengetahuan investor.

Penelitian akuntansi sebelumnya juga telah memfokuskan sebagian besar pada pemeriksaan eskalasi komitmen dalam keadaan di mana individu-individu secara pribadi bertanggung jawab atas tindakan (mis., Kanodia et al. 1989; Chow et al.1997) dan mengidentifikasi bagaimana prosedur insentif dan pengendalian dapat didesain untuk mencegah perilaku eskalasi oleh manager yang bertanggung jawab untuk awal keputusan proyek investasi (mis. Harrell dan Harrison 1994; Ghosh 1997).

Keputusan seseorang, sangat dipengaruhi oleh Informasi yang disajikan, seperti yang dikembangkan oleh teori prospek (Kahneman dan Tversky, 1979). Risk Seeker, meski informasi dibingkai dengan informasi negative, tetap menempuh jalan yang sudah diambil, dan diyakini oleh mereka. Demikian pula, mereka akan tetap memilih perilaku berisiko merugikan ketika mereka memiliki informasi dibingkai positif. Bazerman (1984) menunjukkan bahwa penelitian eskalasi sebelumnya mungkin telah dipengaruhi oleh bagaimana informasi dibingkai. Rutledge dan Harrell (1993) menunjukkan bahwa framing dapat memiliki efek diprediksi kuat pada individu dalam situasi eskalasi. Namun, itu tidak pantas untuk mengasumsikan bahwa hasil ini dapat diperpanjang untuk kelompok pengambilan keputusan konteks.

Penelitian ini dilakukan pada Mahasiswa Prodi Akuntansi dan Prodi Manajemen Universitas Singaperbangsa Karawang, yang berjumlah 80 orang dan mahasiswa yang sudah mengambil matakuliah Manajemen Keuangan dan Akuntansi Manajemen, sehingga diharapkan mampu memahami apa yang akan diselesaikannya dalam kasus ini. Di sini digunakan dua kelompok subyek eksperimen yaitu subyek yang memiliki latar belakang pendidikan akuntansi dan subyek yang memiliki latar belakang manajemen. Variabel yang diselidiki adalah keputusan para subyek untuk meneruskan atau tidak proyek yang sudah berjalan. Di samping untuk melihat bagaimana kemampuan efek framing sebagai moderasi eskalasi komitmen.

Banyak penelitian sebelumnya dalam konteks bisnis telah meneliti efek dari framing (cf Payne et al, 1980; Hershey dan Schoemaker, 1980; Mowen dan Mowen, 1986; Budescu dan Weiss, 1987; Rutledge dan Harrell, 1993). Dalam rangka meningkatkan pemahaman tentang isu-isu yang dibahas di atas, penelitian ini menguji beberapa pertanyaan penelitian.

\section{KAJIAN PUSTAKA DAN PEGEMBANGAN HIPOTESIS}

Bagian ini membahas literatur sebelum berhubungan dengan eskalasi komitmen dan membahas hubungan antar variabel yang dibahas dalam penelitian ini. Tinjauan teori ini adalah dasar untuk hipotesis yang diajukan. Tinjauan pertama adalah membahas hubungan antara Latar Belakang Pendidikan dengan Eskalasi Komitmen. Berikutnya, framing diperkenalkan, termasuk diskusi tentang efek moderat potensinya. Ini adalah dasar untuk hipotesis kedua.

\section{Pengaruh Latar belakang pendidikan terhadap Efek eskalasi $\left(\mathbf{H}_{1}\right)$}

Staw (1976) adalah orang yang pertama untuk menyajikan hasil tes empiris efek eskalasi. Brockner (1992) dalam suatu sintesis atas literatur-literatur sebelumnya, menyatakan bahwa "eskalasi komitmen tampaknya adalah hasil dari sejumlah faktor dan proses". Sedangkan Bazerman (1994) mengkategorikan penyebab atau determinan eskalasi itu dapat dibagi oleh sebab bias perseptual, bias judgmental, manajemen impresi dan irasionalitas yang kompetitif. Kategori lain determinan eskalasi menurut Staw dan Ross (1986) adalah sifat proyek itu sendiri, variabel psikologis, sosial dan organisasional. Beberapa penelitian kemudian menggunakan kerangka teori agensi (Harrison dan Harell, 1993; Harrell dan Harrison, 1994; Goedono dan Sami, 2003) dan teori prospek (Whyte, 1986; Rutledge dan Harrell, 1993) dalam mengidentifikasi faktor dan proses yang menjelaskan perilaku eskalasi ini. 
Hasil Staw dan rekan-rekannya menunjukkan bahwa tanggung jawab yang dirasakan dari pembuat keputusan akan cenderung meningkatkan preferensi untuk investasi tambahan dari sumber di bawah risiko hasil negatif terus (misalnya Bazerman et al. , 1984; Rutledge dan Harrell, 1993). Satu-satunya penelitian mencatat eskalasi komitmen dalam pengambilan keputusan kelompok adalah Bazerman et al. (1984). Menggunakan tugas dimodifikasi dari Staw (1976), mereka menemukan eskalasi komitmen terjadi untuk empat kelompok mata pelajaran.

Beberapa peneliti (Bazerman, 1984; Kahneman dan Tversky, 1979) menggunakan teori prospek sebagai Rerangka dalam eskalasi komitmen. Mereka memusatkan analisisnya pada bagaimana informasi disajikan dan pemprosesan kognitifnya. Whyte (1986) dalam penelitiannya mengatakan bahwa eskalasi komitmen dapat diterangkan oleh fungsi nilai menurut teori prospek. Dalam teori prospek, tiap keputusan dibuat setelah informasi terlebih dahulu disaring melalui 'decision frame' atau 'bingkai keputusan' oleh pengambil keputusan atau "konsepsi atas tindakan, hasil dan kontinjensi yang berkaitan dengan pilihan tertentu" (Kahneman dan Tversky, 1979). Konsekuensi dari pembingkaian ini adalah pilihan berisiko, bila diproses melalui fungsi nilai yang cekung pada keadaan untung (perceived gain) dan cembung pada kondisi rugi (perceived loss), menghasilkan perilaku mencari risiko (risk-seeking) pada hasil rugi dan penghindaran risiko (risk-averse) pada hasil yang untung.

Studi yang dilakukan Amelia (2014) menemukan bahwa latar belakang pendidikan mengurangi pengaruh pembingkaian keputusan atas pertimbangan melanjutkan proyek. Subyek yang berlatar belakang pendidikan akuntansi tidak dipengaruhi oleh jenis pembingkaian informasi proyek dalam melakukan pertimbangannya. Dari beberapa riset yang ada, dan telah diterangkan di atas, maka dalam hipotesis 1 dalam penelitian ini adalah:

H1: Kelompok dengan latar belakang pendidikan yang berbeda, memiliki pengaruh terhadap efek eskalasi yang berbeda dalam proyek yang menghadapi potensi kegagalan.

Pengaruh Framing sebagai variable
moderasi pada kelompok dengan latar
belakang pendidikan yang berbeda
terhadap Efek eskalasi $\left(\mathrm{H}_{2}\right)$

Keputusan yang dibuat dalam situasi eskalasi melibatkan pengambilan keputusan dalam kondisi risiko. Kahneman dan Tversky (1979) mengembangkan teori prospek setelah mencatat bahwa beberapa aksioma teori utilitas yang diharapkan seringkali dilanggar. Teori prospek menunjukkan bahwa eskalasi komitmen mungkin terjadi karena framing pilihan sebagai keuntungan atau kerugian (Bazerman, 1984; Arkes dan Blumer, 1985; Whyte, 1986).

Dalam konteks keputusan investasi, seorang pengambil keputusan yang menerima umpan balik negatif atas keputusan investasi sebelumnya akan berada pada posisi atau kondisi rugi, dan akan memandang keputusan berikutnya sebagai pilihan antara kerugian pasti yang telah terjadi (yaitu memilih untuk tidak melanjutkan tindakan menambah investasi) dengan kerugian di masa mendatang yang kurang pasti (yaitu mengambil risiko menambah dana dengan harapan mendapat pengembalian positif). Bingkai keputusan yang diadopsi sebagian dikendalikan oleh framing positif dan negatif dari informasi yang digunakan oleh pembuat keputusan. framing positif berarti informasi yang dirumuskan dalam hal pengaruhnya terhadap kemampuan untuk mencapai suatu peristiwa atau objek. framing negatif berarti informasi yang dirumuskan dalam hal pengaruhnya terhadap kemampuan bukan untuk mencapai suatu peristiwa atau objek. keyakinan dan tindakan pembuat keputusan yang kuat dan diduga dipengaruhi oleh cara di mana keputusan informasi yang relevan dibingkai. Efek dari framing yang ditunjukkan dalam sejumlah besar hasil penelitian (misalnya Payne et al, 1980, 1981;. Tversky dan Kahneman, 1981; Mowen dan Mowen, 1986; Budescu dan Weiss, 1987).

Dalam keadaan ini, pengambil keputusan cenderung untuk mencari risiko, memilih kerugian yang tidak pasti yang memberikan harapan perbaikan (komitmen tambahan dana) dibandingkan kerugian yang pasti. Sebaliknya jika informasi disajikan dengan bingkai keputusan positif, pengambil keputusan diperhadapkan pada pilihan antara untung yang pasti (pengembalian investasi yang semula) dengan keuntungan di masa mendatang yang tidak pasti. Dalam keadaan ini, pengambil keputusan akan cenderung menghindari risiko dengan mengambil keuntungan yang pasti daripada menghadapi risiko keuntungan yang 
tidak pasti, dengan tidak melanjutkan proyek (Bateman dan Zeithaml, 1989; White, 1986). Bazerman (1984) mencatat bahwa informasi yang diberikan kepada peserta dalam studi eskalasi sebelum tampaknya dibingkai negatif. Dia menyarankan bahwa pengambil keputusan tidak selalu bertindak dengan cara yang nonrasional, melainkan mereka mungkin telah bertindak konsisten dengan prinsip teori prospek.

Untuk itu dalam hipotesis kedua ini, peneliti ingin mengetahui Jika penelitian eskalasi sebelum itu sengaja dipengaruhi oleh framing informasi keuangan yang diberikan kepada peserta, maka untuk itu perlu mempertimbangkan dampak framing sebagai variable moderasi pada kelompok latar belakang pendidikan yang berbeda terhadap efek eskalasi.

$\mathrm{H} 2$ : Pembingkaian informasi keuangan yang diberikan kepada kelompok dengan latar belakang pendidikan yang berbeda memiliki potensi untuk memoderasi efek eskalasi.

\section{METODE PENELITIAN}

\section{Subyek}

Subyek yang berpartisipasi dalam eksperimen adalah mahasiswa S1 Fakultas Ekonomi dan Bisnis Prodi Akuntansi dan Prodi Manajemen Unsika, yang telah menempuh matakuliah Akuntansi Manajemen, sebanyak 80 orang dikelompokkan atas dua kelompok. Subyek yang berasal dari latar belakang pendidikan akuntansi terdiri dari 40 orang dan dari mahasiswa latar belakang manajemen terdiri dari 40 orang. Penelitian ini seluruhnya menggunakan eksperimen laboratorium secara murni.

\section{Desain eksperimental dan Metode}

Metode penelitian ini merupakan Penelitian dengan rancangan eksperimen. Metode eksperimen ditujukan untuk meneliti hubungan sebab akibat dengan memanipulasi satu atau lebih variable pada satu (atau lebih) kelompok eksperimental, dan membandingkan hasilnya dengan kelompok control yang tidak mengalami manipulasi. (I Putu Ade dan I Gusti Agung, 2018). Penelitian ini merupakan penelitian factorial design $(2 \times 2)$ yang termasuk dalam Beetween Group Design. Variabel dependen adalah kecenderungan eskalasi yang diukur dengan pertimbangan untuk melanjutkan proyek. Variabel independen (faktor-faktor) adalah Latar Belakang Pendidikan dan Variabel Framing sebagai variable moderator.

Pembingkaian atau framing dimanipulasi dengan mengungkapkan adanya biaya yang sudah terjadi (sunk cost) sebagai kerugian (loss), dan mendeskripsikan pilihan eskalasi sebagai kesempatan untuk menghindari kerugian yang sudah terjadi. Penelitian ini melakukan randomisasi terhadap perlakuan (treatment) yang diberikan. Randomisasi dilakukan dengan memastikan bahwa setiap subjek hanya menerima satu kasus dari 4(empat) kemungkinan kombinasi kasus. Tujuan randomisasi dalam penelitian ini adalah untuk menghasilkan jumlah subjek yang hampir sama untuk setiap perlakuan.

Pada eksperimen ini, digunakan adaptasi kasus dari Rutledge (1995). Informasi dalam kuesioner meminta subyek berada pada posisi sebagai seorang manajer senior yang telah mengambil keputusan investasi berkaitan dengan proyek riset dan pengembangan produk baru setahun sebelumnya. Umpan balik negatif disajikan dengan menyebutkan bahwa ada pesaing yang juga menghasilkan produk serupa yang lebih unggul dibandingkan produk perusahaan. Bagian selanjutnya menginformasikan perlunya investasi tambahan untuk mengatasi masalah ini. Kemudian kepada subyek diberikan bingkai keputusan atas dua pilihan. Bila bingkai keputusan negatif, keadaan ini digambarkan sebagai kerugian, dengan dua pilihan yaitu kerugian pasti (tidak melanjutkan proyek) dan kerugian tidak pasti (tetap melanjutkan proyek). Bila bingkai keputusan positif, keadaan ini diuraikan sebagai keuntungan yaitu keuntungan pasti (tidak melanjutkan proyek atau berarti menghemat tambahan investasi) dan keuntungan tidak pasti (melanjutkan proyek). Selanjutnya subyek diminta menuliskan pertimbangan mereka melanjutkan proyek dalam skala 1

Mereka telah membaca kasus selama kurang lebih tujuh menit sebelum ditugaskan untuk dua kelompok yang berbeda latar belakang pendidikannya. Kira-kira setengah dari kelompok menerima informasi yang menunjukkan bahwa mereka dianjurkan investasi awal dalam proyek; kelompok yang tersisa menerima informasi yang menunjukkan bahwa mereka tidak bertanggung jawab atas pilihan awal.

Manipulasi eksperimental ini dilakukan dalam rangka untuk menguji hipotesis pertama $(\mathrm{H} 1)$. Dalam rangka untuk menguji hipotesis kedua 
(H2), masing-masing dari kelompok diberikan informasi kasus yang berbingkai positif dan negative. Yang positif, menekankan potensi penghematan, sedangkan informasi kasus negatif dibingkai dengan menekankan potensi kerugian.

\section{Kuesioner Eksperimen}

Instrumen menggunakan adaptasi kasus dari Rutledge (1995). Penelitian ini mengambil vignette kasus dengan kondisi pembingkaian negatif dan positif (atau netral) dari Rutledge (1995). Instrumen berupa kuesioner yang diujikan dapat dilihat sebagai berikut:

\section{Instruksi}

Dalam kasus yang diuraikan di bawah ini anda diminta untuk berperan dalam posisi manajer perusahaan yang bertanggung jawab untuk membuat keputusan. Harap anda baca bagian kasus ini secara cermat dan anda diminta untuk membuat keputusan. Keputusan yang anda buat tidak dinilai sebagai jawaban yang benar atau salah dan anda harus menggunakan pertimbangan anda yang profesional.

\section{HASIL DAN PEMBAHASAN}

Respon atas kuesioner eksperiment oleh para subyek penelitian dianalisis dengan Model ANOVA faktorial $2 \times 2$ dengan latar belakang pendidikan dan jenis pembingkaian keputusan sebagai variable moderasi, dan keputusan melanjutkan proyek sebagai variabel dependen. Subyek diminta untuk membuat pertimbangan untuk melanjutkan proyek yang tidak menguntungkan atau menghentikan proyek tersebut pada skala poin 1 sampai 6 (berkisar dari "sangat setuju dengan menghentikan proyek" sampai "sangat setuju melanjutkan proyek").

\section{Analisis Pengaruh utama untuk Latar Belakang Pendidikan (H1)}

Variabel latar belakang pendidikan untuk menguji efek eskalasi dalam pengambilan keputusan. Artinya, perbedaaan latar belakang pendidikan, akuntansi atau non akuntansi diharapkan memiliki preferensi yang berbeda dalam menguji efek eskalasi dalam pengambilan keputusan.

Tabel. 1: Mean Pertimbangan Melanjutkan Proyek Berdasarkan Kondisi-Kondisi (deviasi standar dalam tanda kurung)

\begin{tabular}{|c|c|c|}
\hline \multirow{2}{*}{ Framing } & \multicolumn{2}{|c|}{$\begin{array}{c}\text { Latar belakang } \\
\text { Pendidikan }\end{array}$} \\
\cline { 2 - 3 } & Akuntansi & Manajemen \\
\hline Negatif & 4.45 & 3.00 \\
\hline & $(0.826)$ & $(1.124)$ \\
\hline Positif & 4.00 & 4.05 \\
\hline & $(0.795)$ & $(1.099)$ \\
\hline
\end{tabular}

Tabel 1 memperlihatkan statistic deskriptif atas pertimbangan melanjutkan proyek dari subyek yang berlatar belakang pendidikanmyang berbeda, yang satu Prodi akuntansi dan yang lain adalah Prodi Manajemen. Tabel 1 memperlihatkan jika kepada subyek yang berlatar belakang akuntansi disajikan informasi proyek dengan cara pembingkaian keputusan negatif mean pertimbangan melanjutkan proyek mereka tidak berbeda secara signifikan dibandingkan dengan bila kepada mereka disajikan informasi proyek berbingkai keputusan positif (mean 4,45 dan 4,00). Mean preferensi kelompok Akuntansi dengan kasus dibingkai positif adalah 4,00 sedangkan preferensi rata-rata kelompok Akuntansi dengan kasus dibingkai negatif adalah 4,45. Selain itu, kecenderungan kelompok Akuntansi untuk mengurangi investasi ketika mereka tidak bertanggung jawab atas investasi awal dalam situasi eskalasi dimoderatori oleh framing positif (4,55 untuk framing negatif vs 4,00 untuk framing positif, $\mathrm{p}<0,05)$. Dengan demikian, kelompok Akuntansi memiliki preferensi untuk tetap melanjutkan proyek gagal (tidak menguntungkan), apapun pembingkaian informasinya, baik ketika disajikan dengan informasi dibingkai negatif maupun ketika disajikan dengan informasi dibingkai secara positif.

Sebaliknya, subyek yang memiliki latar belakang manajemen apabila disajikan informasi proyek berbingkai negatif mempunyai mean pertimbangan melanjutkan proyek yang lebih rendah $($ mean $=3,00$ ) dibandingkan apabila informasi yang disajikan berbingkai positif (mean $=4,05$ ). Analisis lebih lanjut dari data menemukan bahwa efek framing berada di arah yang diprediksi dari pembahasan teoritis, di atas. Artinya, kecenderungan kelompok Manajemen untuk meningkatkan investasi karena "tanggung jawab" dalam situasi eskalasi dimoderatori framing (bertambah), pada framing positif dari 
informasi yang diterima (3,00 untuk framing negatif vs 4,05 untuk framing positif, $\mathrm{p}<0,05$ ).

Tabel. 2: Hasil Uji Hipotesis

Tests of Between-Subjects Effects

Dependent

\begin{tabular}{|l|r|r|r|r|r|}
\hline & \multicolumn{1}{|c|}{ VKariable: } \\
\hline Source & $\begin{array}{r}\text { Type III } \\
\text { Sum of } \\
\text { Squares }\end{array}$ & df & \multicolumn{1}{c|}{$\begin{array}{c}\text { Mean } \\
\text { Square }\end{array}$} & \multicolumn{1}{c|}{ F } & Sig. \\
\hline Corrected & $22.850^{\mathrm{a}}$ & 3 & 7.617 & 8.051 & .000 \\
Model & 1201.250 & 1 & 1201.250 & 1269.750 & .000 \\
Intercept & 1.800 & 1 & 1.800 & 1.903 & .172 \\
FRAM & 9.800 & 1 & 9.800 & 10.359 & .002 \\
BG & 11.250 & 1 & 11.250 & 11.892 & .001 \\
FRAM * BG & 71.900 & 76 & .946 & & \\
Error & 1296.000 & 80 & & & \\
Total & 94.750 & 79 & & & \\
Corrected & & & & \\
Total & & & & & \\
\hline
\end{tabular}

a. R Squared $=.241$ (Adjusted R Squared $=.211)$

Ket:

Fram : Framing (pembingkaian)

BG : Back Ground Pendidikan

EK : Eskalasi Komitmen

Pada Tabel 2, disajikan hasil uji hipotesis, pada variable Latar Belakang pendidikan, Framing maupun Eskalasi Komitmen. Hasil di atas menunjukkan bahwa Latar Belakang Pendidikan berpengaruh terhadap Eskalasi Komitmen dengan signifikan secara statistik $\rho(0,002<0,05)$. Hasil ini mendukung mendukung hipotesis $\mathrm{H} 1$.

\section{Analisis Efek Framing sebagai Variabel Moderasi (H2)}

Variabel framing dimanipulasi untuk menguji efeknya pada kelompok pengambil keputusan dalam situasi eskalasi. Seperti dapat dilihat dari Tabel 2, framing mampu memoderasi hubungan antara variable latar belakang pendidikan dengan eskalasi komitmen yang ditunjukkan dengan tingkat signifikansi secara statistik $\rho(0,001<0,05)$. Hasil ini menunjukkan adanya interaksi antara variable latar belakang pendidikan dengan framing sebagai moderator mampu mempengaruhi eskalasi komitmen. Hasil ini mengindikasikan bahwa pertimbangan subyek eksperiment yang tidak berlatar belakang pendidikan akuntansi, dalam hal ini manajemen amat dipengaruhi oleh pembingkaian keputusan yang disajikan kepada mereka dan pembingkaian ini tidak secara signifikan memengaruhi pertimbangan subyek yang berlatar belakang pendidikan akuntansi. Hasil di atas juga membuktikan bahwa framing dalam penelitian ini merupakan variable moderasi murni. Pure moderasi merupakan variabel yang memoderasi hubungan antara variabel prediktor dan variabel tergantung di mana variabel moderasi murni berinteraksi dengan variabel prediktor tanpa menjadi variabel prediktor.

Dengan demikian, penelitian ini mendukung hipotesis $\mathrm{H} 2$, dimana terbukti bahwa framing mampu memoderasi hubungan antara variable latar belakang pendidikan dan eskalasi komitmen. Hasil ini mengindikasikan bahwa pertimbangan subyek eksperiment yang tidak berlatar belakang pendidikan akuntansi amat dipengaruhi oleh pembingkaian keputusan yang disajikan kepada mereka dan pembingkaian ini tidak secara signifikan memengaruhi pertimbangan subyek yang berlatar belakang pendidikan akuntansi

Framing meski berdampak pada orang awam seperti dikonfirmasikan banyak penelitian, dalam penelitian ini tidak berpengaruh terhadap eskalasi komitmen. Hasil studi ini mengindikasikan bahwa efek pembingkaian yang didasarkan pada teori prospek tidak dapat seluruhnya menjelaskan terjadinya eskalasi komitmen. Efek pembingkaian dengan demikian hanya merupakan kekuatan penjelas (explanatory power) untuk determinan eskalasi komitmen seperti yang dinyatakan oleh Brockner (1992). Mengingat efek pembingkaian hanya merupakan kekuatan penjelas, maka dia tidak dapat digeneralisasikan kepada setting bisnis dunia nyata. Dalam bisnis yang nyata, berbagai faktor baik dari factor proyek, faktor pribadi atau individual pengambil keputusan, maupun factor organisasi turut berperan dalam menyebabkan perilaku eskalasi. Efek pembingkaian hanya berdampak pada pemprosesan kognitif pribadi pengambil keputusan, sehingga perannya terbatas dan berhadapan dengan faktor-faktor lain yang lebih dominan dalam menentukan terjadinya eskalasi komitmen

\section{SIMPULAN DAN SARAN}

Tujuan dari penelitian ini adalah untuk menyelidiki apakah faktor-faktor latar belakang 
pendidikan mempengaruhi keputusan dalam situasi eskalasi untuk meneruskan atau proyek yang tidak menguntungkan. Selain itu, penelitian ini meneliti efek moderat variable framing dari variable latar belakang pendidikan terhadap variable eskalasi keputusan menghadapi proyek yang tidak menguntungkan. Dua hipotesis penelitian dikembangkan dan diuji dalam percobaan laboratorium menggunakan $2 \times 2$ desain eksperimental. Latar belakang pendidikan dimanipulasi untuk menguji keberadaan efek eskalasi pada kelompok, dan framing dimanipulasi untuk menguji efek moderat potensial.

Sebuah hasil yang signifikan secara statistik ditemukan untuk variable latar belakang pendidikan. Ini mendukung H1, menunjukkan bahwa terdapat perbedaan rerata kelompok Akuntansi dan Non Akuntansi dalam eskalasi pengambilan keputusan. Untuk mendukung $\mathrm{H} 2$, ditemukan bahwa kecenderungan meningkat ketika kelompok Akuntansi berkurang ketika informasi yang dibingkai positif dibandingkan dengan ketika informasi negatif dibingkai. Hal ini menunjukkan bahwa hasil penelitian sebelumnya tentang efek eskalasi mungkin telah sengaja dipengaruhi oleh cara di mana informasi keuangan disajikan untuk subyek (seperti yang disarankan oleh Bazerman, 1984). Akhirnya, ditemukan bahwa kecenderungan untuk menarik diri dari proyek ketika kelompok-kelompok pengambilan keputusan yang "Manajemen" dimoderatori oleh framing negatif (dibandingkan dengan framing positif).

Temuan dan implikasi setiap studi harus dipertimbangkan dalam konteks kekuatan dan keterbatasan. Eksperimen jenis ini memungkinkan pengambilan keputusan perilaku dipelajari dalam lingkungan yang terkendali dan dengan demikian memiliki potensi untuk validitas internal yang tinggi. Namun, hati-hati harus digunakan dalam mengeneralisasi hasil eksperimen tersebut kepada kelompok lain dan situasi lain. Peringatan biasa untuk eksperimen terkontrol berlaku untuk penelitian ini.

Sebagai contoh, meskipun peserta studi memiliki pengalaman di bidang akuntansi yang cukup lama (sebelum memasuki dunia perkuliahan), termasuk pengalaman penganggaran, mereka tidak dipilih secara acak dari populasi semua mahasiswa dan karena itu mungkin tidak mewakili populasi ini.
Selanjutnya, meskipun kasus keputusan tampaknya berisi semua informasi yang diperlukan untuk keputusan yang diperlukan, mereka, tentu saja, abstraksi sederhana dari situasi dunia nyata yang mereka wakili.

Hasil penelitian ini menyiratkan bahwa pengalaman yang mereka miliki, mungkin tidak sengaja mempengaruhi keputusan yang dibuat oleh kelompok berinteraksi. Manajemen akuntan memberikan informasi dalam peran pendukung keputusan mereka, dan harus dibuat sadar akan dampak framing pada keputusan yang dibuat oleh kelompok. Terakhir, seperti yang dibahas sebelumnya, hasil menyiratkan bahwa temuan eskalasi sebelumnya mungkin perlu dikaji ulang mengingat efek framing.

\section{REFERENSI}

Arkes, H. R., \& Blumer, C. 1985. The psychology of sunk cost. Organizational Behavior and Human Decision Processes, 35(1), 124-140. doi:10.1016/0749-5978(85)90049-4

Bateman, T. S., \& Zeithaml, C. P. 1989. The psychological context of strategic decisions: A test of relevance to practitioners. Strategic Management Journal, 10(6), 587-592.

Bazerman, M.H. 1994. Judgment in Managerial Decision Making, 3rd ed., New York, NY: Wiley.

Bazerman, M.H. 1994. Judgment in Managerial Decision Making, 3rd ed., New York, NY: Wiley

Brockner, J, 1992. "The Escalation of Commitment to a Falling Course of Action: Toward Theoretical Progress." Academy of Management Review 17 (1)

Budescu, D. V., \& Weiss, W. 1987. Reflection of transitive and intransitive preferences: A test of prospect theory. Organizational Behavior and Human Decision Processes, 39(2), 184-202.

Budescu, D. V., \& Weiss, W. 1987. Reflection of transitive and intransitive preferences: A test of prospect theory. Organizational Behavior and Human Decision Processes, 39(2), 184-202.

Chong dan Syarifuddin. 2010. "Escalation of Comitment to unprofitable projects : An Experimental Investigation of The Effect of Conformity Pressure and Self- 
Esteem", Accounting, Accountability \& Performance, Vol. 16, No. 1\&2..

Chow, C.W., P. Harrison, T. Lindqvist dan A. Wu. 1997. Escalating commitment to unprofitable projects: replication and cross-cultural extension. Management Accounting Research, 8: 347-361.

Effriyanti. 2005. Pemanfaatan Informasi Akuntansi Untuk Menghindari Eskalasi Komitmen Pada Level Pengambilan Keputusan, Simposium Nasional Akuntansi VIII, Solo,September: 747758.

Effriyanti. 2005..Pemanfaatan Informasi Akuntansi Untuk Menghindari Eskalasi Komitmen Pada Level Pengambilan Keputusan. Universitas IBA Palembang. Simposium Nasional Akuntansi VIII Solo

Ghosh, D. 1997. De-escalation strategies:some experimental evidence. Behavioral Research in Accounting 9: 88-112.

Goedono, Mohamad dan Heibatollah Sami. 2003. Managers' adverse selection in resource allocation: A laboratory experiment. Advances in Management Accounting, Vol. 11, p: 225-249

Harrell, Adrian dan Harrison Paul D. 1993. Impact of 'Adverse Selection' on Managers' Project Evaluation Decisions. Academy of Management Journal. Vol. 36. No. $3: 635-643$.

Hasibun, Malayu S.P.2009. Manajemen. Cet III, Jakarta: Bumi Aksara.

Hershey, J. C., and Schoemaker, P. J. H. 1980. Risk taking and problem context in the domain of losses: An expected utility analysis. Journal of Risk and Insurance 47:111-32.

I Putu Ade A.P. dan I Gusti Ngurah T.J.2018. Panduan Penelitian Eksperimen Beserta Analisis Statistik dengan SPSS.Jogjakarta.Deepublish

Kahneman, D., \& Tversky, A. 1979. Prospect theory: An analysis of decision under risk. Econometrica, 47, 263-291.

Kanodia, Chandra, Robert Bushman dan John Dickhout. 1989. Escalation errors and the sunk cost effect: An explanation based on reputation and information asymmetries. Journal of Accounting

Research, Vol. 27, No. 1, p: 59-77

Kanodia, C., R. Bushman dan J.Dickhaut. 1989.

Escalation errors and the sunk cost effect: an explanation based on reputation and information asymmetries. Journal of Accounting Research, 27: 5977.

Mowen, M.M. and Mowen, J.C. 1986."An Empirical Examination of the Biasing Effects of Framing on Business Decisions", Decision Sciences, 17, 596602.

Payne, J. W.; Laughhunn, D. J.; and Crum, R. 1980. Translation of gambles and aspiration level effects in risky choice behavior. Management Science 26:103960.

Rahmawati, Y.S., dan Q. Nurul. 2006. Pengaruh Asimetri Informasi Terhadap Praktik Manajemen Laba pada Perusahaan Perbankan Publik yang Terdaftar di Bursa Efek Jakarta, Simposium Nasional Akuntansi IX, Padang, Agustus.

Rahmawati, Yacob Suparno, Nurul Qomariyah.2006. "Pengaruh Asimetri INformasi Terhadap PraktikManajemen Laba pada Perusahaan PerbankanPublik Yang Terdaftar Di Bursa Efek Jakarta",Simposium Nasional Akuntansi VI Padang.

Rutledge, R. W., \& Harrell, A. M. (1993). Escalating commitment to an ongoing project: Theeffects of responsibility and framing of accounting information.International Journal ofManagement, 10, 300-314

Singer, Ming dan Singer, Alan E. 2001. "Individual Differences and The Escalation of Commitment Paradigma". The Journal of Social Psychology.

Staw, B. M. 1976. "Knee-Deep in the Big Muddy: A Study of Escalating Commitment to a Chosen Course of Action." Organizational Behavior and Human Resourses 16.

Staw, B.M dan J. Ross. 1986. "Understanding behavior in escalation situations". Science246 (October): 216-220

Suartana, I.W., 2010, Akuntansi Keperilakuan: Teori dan Implementasi, Yogyakarta: ANDI. 
Suwardjono, 2005, Teori Akuntansi; Perekayasaan Pelaporan keuangan, Edisi Ketiga.Yogyakarta, BPFE.

Whyte, G. 1986. Escalating commitment to a course of action: a reinterpretation. Academy of Management Review, 11: 311-321

Yunia Amelia.,2014. Framing-Effect As A Determinant Escalation Manager Commitment Of Investment Decision: Impact Of Educational Background And Non Accounting And Accounting. Jurnal Ilmiah Gema Ekonomi.Vol. 4, No. 2 Agustus 2014.Hal. 467 